\title{
Toxicity of building materials: a key issue in sustainable construction
}

\author{
Fernando Pacheco-Torgal $^{\mathrm{a} *}$ and Said Jalali ${ }^{\mathrm{b} 1}$ \\ ${ }^{a}$ C-TAC Research Unit, University of Minho, 4800 Guimarães, Portugal; ${ }^{b}$ Department of Civil Engineering, University of Minho, \\ 4800 Guimarães, Portugal
}

(Received 13 December 2010; final version received 1 March 2011)

\begin{abstract}
To avoid the use of toxic building materials is one of the principles of sustainable construction. However and contrary to general beliefs, current residential buildings frequently contain many toxic building materials, some of which even comply with legal regulations. Part of the problem is because architects and civil engineers have no form of knowing the toxicity of building materials. The other part is economically related. Some regulations about toxicity limits are influenced by economic reasons. For instance, although scientific evidence about the toxicity of lead plumbing has existed for quite some time, legal regulations avoid imposing very tight thresholds because of the cost of lead pipe substitution (in Europe that could cost almost 200,000 million euros). It is then no surprise to see that the related Directive (98/83/CE) established a 15 -year delay period before the $10 \mu \mathrm{g} / \mathrm{l}$ lead content threshold is enforced. This paper discusses some cases of toxic building materials by reviewing previously published work, it also covers the emission of volatile organic compounds from paints and varnishes, the toxicity of impregnating agents, materials that release toxic fumes during a fire, asbestos-based materials, radioactive materials and lead plumbing.
\end{abstract}

Keywords: toxic materials; lead plumbing; VOCs; radioactivity; asbestos

\section{Introduction}

Our planet faces a major challenge that if not solved, or if it is just postponed, may lead to the end of our civilisation, as we know it. Humans use many kind of resources, including non-renewable ones, leaving traces of pollution in the consumption process, and only a few people consume the majority of resources to make things worse (Meadows et al. 1972, WWI 2009). The immediate effects of civilisations' consumption patterns, with the consequences for nations and for future generations, have never been revealed in inter-generational and inter-geographic dimensions (Stern 2006). A recent report of the Intergovernmental Panel on Climate Change (IPCC 2007) mentioned that rising sea levels would have, therefore, approximately 200 million refugees. Environmental worries in the modern society have increased since 1972 when the United Nations Conference about the Environment took place in Stockholm. But it was only in 1987 that they gained a wider impact after the publication of the report 'Our Common Future', also known as the Bruntland Report (Bruntland 1987), in which the concept of sustainable development first appears as the one 'that allows the fulfilment of current needs without preventing the needs of future generations'. The construction industry is responsible for the depletion of large amounts of non-renewable resources and for the carbon dioxide gas emissions. To achieve a more sustainable construction, the European Union recently established that in a medium term, raw material consumption must be reduced by $30 \%$ and that waste production in this sector must be cut by $40 \%$. Although sustainable resource consumption is of paramount importance for sustainable construction, building material's toxicity is no less important. While our ancestors lived in buildings made of raw materials, nowadays residential buildings contain thousands of chemicals and heavy metals, polluting indoor air or contaminating tap water. Thus causing several healthrelated problems such as asthma; itchiness; burning eyes, skin irritations or rashes, nose and throat irritation; nausea; headache; dizziness; fatigue; reproductive impairment; disruption of the endocrine system; impairing child development and birth defects; immune system suppression and cancer. Beyond the toxicity of indoor building materials, one must not forget also the toxicity potential during the production of such chemicals. Remember for instance the Bhopal disaster that occurred in India, in 1984, when a cloud of methyl isocyanine caused almost 15,000 deaths and health problems in almost 200,000 human beings (Varma and Mulay 2006, Satyanand 2008). During the production of chemical materials, hazardous wastes are generated, and that impact must be associated to building materials containing these chemicals. The most common toxic chemicals are the following:

*Corresponding author. Email: torgal@ civil.uminho.pt

ISSN 1939-7038 print/ISSN 1939-7046 online

(C) 2011 Taylor \& Francis

DOI: $10.1080 / 19397038.2011 .569583$

http://www.informaworld.com 


\subsection{Dioxins and furans}

Dioxins and furans are the chemical waste generated in the industrial process evolving chlorine as it occurs in PVC production. Dioxins and furans are extremely toxic and bio-cumulative (IARC 1997, Lanting et al. 1998). This has hazardous effects in biodiversity by contaminating all of the food chain (Oppenhuizen and Sijm 1990, Tillitt et al. 1993). According to Thornton (2000) in the last four centuries the concentration of dioxin and furans in sediment cores from the Baltic region and in two German lakes increased from zero to almost $100 \%$. Furthermore, chemical analysis carried out on dolphins in the northern Pacific Ocean revealed dioxin and furan concentrations between 13 and 37 million times higher than water concentrations (Thorton 2000). Several scientist groups already suggest that chlorine industrial-based production should be prohibited (Flores et al. 2004).

\subsection{Phthalates}

These are the chemical compounds formed due to phthalic acid. Phthalates are used to soften plastic materials. Several studies show that phthalates are very toxic to human health (Lovekamp-Swan and Davis 2003, Hauser and Calafat 2005, Heudorf et al. 2007, Swan 2008, Wolff et al. 2008, Meeker et al. 2009).

\subsection{Volatile organic compounds}

These are the atmospheric pollutants released from the building materials which contain organic solvents like paints and varnishes. The reduction of indoor ventilation to minimise energy consumption (as it often happens in Portugal) contributes to increasing the effects of volatile organic compounds (VOCs) in human health (Sterling 1985, Samfield 1992, Hansen and Burroughs 1999). The importance of this subject will require awareness for everyone; mainly those who will have a major role in climate
Table 1. Cancer agents detected in paints.

\begin{tabular}{ll}
\hline Cancer agent & Likely source \\
\hline Chromates & Primers, paints \\
Cadmium & Pigments \\
Benzene & Solvents \\
Methylene chloride & Paint strippers \\
Styrene & Organic solvents \\
Nikel compounds & Pigments \\
Dichlorobenzidine & Pigments \\
Lead & Primers, dryers, pigments \\
Antimony oxide & Some pigments \\
Nitropropane & Organic solvent \\
Tetrachloroethylene & Organic solvent \\
\hline
\end{tabular}

change issues as in the case of professionals working in construction-related activities (industry or academia). The present paper covers emissions of VOCs from paints and varnishes, the toxicity of wood impregnating agents, the materials that release toxic fumes during a fire, asbestosbased materials, radioactive materials and lead plumbing.

\section{Emission of VOCs from paints and varnishes}

Several authors confirm the release of VOCs from paints and varnishes (Kostianien 1995, Kwok et al. 2003). More recently, Salasar (2007) studied VOCs emissions in solvent- and water-based paints stating that their form is responsible for VOCs emissions, which is 520 times higher than the latter. Paint can also be a source of several cancer agents (Table 1). In Portugal, the legal Decree No. 181/2006 of 6 September corresponds to the EU Directive No. 204/42/CE (21 April 2004). This legislation intended to put a threshold on the VOCs emissions from paints and varnishes (Table 2). One can see that beyond 1 January 2007, the VOCs emissions must be reduced, and beyond 1 January 2010 they must be reduced even more. This means that until the new low VOC paints and varnishes are introduced into the construction market, we all have been breathing very high levels of VOCs.

Table 2. Threshold VOCs emissions from paints and varnishes, Portugal legal Decree No. 181/2006 of 6 September.

\begin{tabular}{|c|c|c|c|}
\hline Product & Type & $\begin{array}{c}\text { Beyond } \\
\text { 1 January } 2007 \\
(\mathrm{~g} / \mathrm{l})\end{array}$ & $\begin{array}{c}\text { Beyond } \\
1 \text { January } 2010 \\
(\mathrm{~g} / \mathrm{l})\end{array}$ \\
\hline \multirow[t]{2}{*}{ (a) Non-glossy paints for interior walls and ceilings } & BA & 75 & 30 \\
\hline & BS & 400 & 30 \\
\hline \multirow[t]{2}{*}{ (b) Glossy paints for interior walls and ceilings } & BA & 150 & 100 \\
\hline & BS & 400 & 100 \\
\hline \multirow[t]{2}{*}{ (c) Paints for exterior walls with mineral substrate } & BA & 75 & 40 \\
\hline & BS & 450 & 30 \\
\hline \multirow[t]{2}{*}{ (d) Paints for interior and exterior wood and metal substrates } & BA & 150 & 130 \\
\hline & BS & 400 & 300 \\
\hline \multirow[t]{2}{*}{ (e) Varnishes and lasures for interior and exterior purposes } & BA & 150 & 130 \\
\hline & BS & 500 & 400 \\
\hline
\end{tabular}

Note: BA, water-based paints; BS, organic solvent-based paints. 


\section{Toxicity of wood impregnating agents}

Although wood is an excellent example for sustainable building, it has low resistance to biologic degradation (fungal and insect attack) (Morrell 2002). Until very recently, wood preservation would mean the use of impregnating agents (insecticides or fungicides) like creosote or others based on salt impregnation like copper, chrome and arsenic (CCA). However, these salts are highly toxic also bio-cumulative. When they are in contact with rainwater, most part of these salts are leached away, contaminating the environment. Since 1 January 2004, the US EPA forbade the use of CCA for wood preservation (Edlich et al. 2005). As to creosote, it contains cancer potential agents (ASTDR 2002, Smith 2008); therefore, since 2001 Directive 2001/90/EC, a process was initiated to ban the use of creosote in wood treatment purposes. Some studies mentioned that wood used in railway cross ties has a high content of creosote (Thierfelder and Sandstrom 2008) so they must be seen as hazardous wastes, meaning that they must be properly immobilised and they can no longer be reused (Pruszinski 1999). The same should happen to all the creosote-treated wood, which in the near future would become construction and demolition waste.

\section{Materials that release toxic fumes during fire}

Another case of building materials toxicity is related to materials that release toxic fumes during a fire. Some studies show that the majority of deaths during fires are due to inhalation of toxic fumes, and that the deaths are increasing since the 1980s, which maybe due to the fact that the amount of combustible materials inside households have increased in the last three decades (Gann et al. 1994, Hall and Harwood 1995, Wu 2001, Levin and Kuligowski 2005). Liang and Ho (2007) studied the toxicity during a fire of several insulation materials concluding that polyethylene foam and polyurethane foam have a toxicity index (TI) above 10, thus meaning a very high toxicity (Figure 1). The IT is obtained from the emissions of 14 different combustible gases to form a deadly concentration after $30 \mathrm{~min}$ exposure. These authors recommend that polyethylene foam and polyurethane foam should not be used unless covered by non-combustible materials. Others (Doroudiani and Omidian 2010) say that polystyrene decorative mouldings should be avoided because polystyrene is a very combustible material, which releases toxic fumes during a fire. They also say that new polystyrene with flame-retardant properties is now being produced, but it also releases other toxic substances.

\section{Asbestos-based materials}

Asbestos covers several mineral fibres with 5- $\mu \mathrm{m}$ length and $3 \mu \mathrm{m}$ in diameter such as chrysolite, crocidolite, amosite, anthrophyllite, tremolite and actinolite. It was not until the



Figure 1. Average value of TI (Liang and Ho 2007). (Reprinted with permission from Elsevier (C) 2007).

1960s that a relation between asbestos exposure and several specific diseases was established by the scientific evidence. By that time, only some mineral fibres (crocidolite - blue asbestos and amosite - brown asbestos) were judged as toxic and responsible for pleural mesothelioma from which most patients died, 12 months after being diagnosed (Bianchi et al. 1997, Jarvholm et al. 1999, Azuma et al. 2009). Chrysolite (white asbestos) was left aside because it was thought that it had a low toxic risk and that is why asbestos continued to be produced. Only in the 1980s with the Directive 83/477/CEE, the asbestos problem started to be taken more seriously. In Portugal only after 6 years, the Decree No. 284/89 of 24 August came into practice the content of Directive 83/477/CEE.After some years the Directive 91/382/EEC, which has enforced even more strict caution about asbestos, and finally Directive 2003/18/EC prohibited the production of asbestos-based products. In the meantime, scientific evidence proved that all mineral fibres present a cancer risk as asbestosis (lung damage due to acid formation in an attempt of the body to dissolve the asbestos fibres) (Akira 2010) or even lung cancer or other types of cancer (Ladou 2004, Silverstein et al. 2009, Antonescu-Turcu and Schapira 2010). Four years later, Portugal adopted the Directive 2003/18/EC by issuing the Decree No. 266/2007 of 24 July which defines a threshold risk (value of limit exposition) when asbestos fibre concentration is higher than $0.1 \mathrm{fibre} / \mathrm{cm}^{3}$. Although some may think asbestos is no longer a problem let, we cannot forget the vast number of fibre cement materials, which are asbestos, based which are still in place. Portugal, for instance, has almost 600,000 ha of fibre cement asbestos roofing sheets. One may argue that 
cement materials containing asbestos have a low toxicity risk but it is also true that cement will loose its binding capacity under environmental erosion, and that some cracking accidents could take place releasing asbestos fibres. Therefore, it is not possible to say that the people working (or living) under those roofing sheets are not subject to fibre concentration higher than the VLE threshold or if people subject to a fibre concentration below VLE will not develop cancer problems after a long-term exposure.

\section{Radioactive materials}

The use of waste materials with some form of radiological contamination is known to be a matter of concern to public health because exposure over a long term even of low doses can develop cancer formations (ICRP 1990). In general, building materials do not show radioactivity levels that deserve concern (Papaefthmiou and Gouseti 2008), but the same cannot be said about some industrial by-products used for concrete production such as phosphogypsum, some blast furnace slags and some fly ashes (Table 3). Some phosphogypsum possesses heavy metals and radioactive elements such as radium $\left({ }^{226} \mathrm{Ra}\right)$, lead $\left({ }^{210} \mathrm{~Pb}\right)$ and uranium $\left({ }^{238} \mathrm{U},{ }^{234} \mathrm{U}\right)$ that come from phosphate rocks (Rihanek 1971). The use of phosphogypsum with a concentration level of $370 \mathrm{~Bq} / \mathrm{kg}$ (in which $1 \mathrm{~Bq}$ corresponds to 1 nuclear disintegration per second) has been prohibited since 1992 (EPA 1992). The Euratom (1996) threshold is $500 \mathrm{~Bq} / \mathrm{kg}$. Since different phosphate rocks possess different radioactivity levels, not all the phosphogypsum can be considered to be radioactive (Canut 2006). Another important case of radioactive contamination is related to radon, a radioactive gas that can be found in some types of phosphogypsum and can be toxic in indoor air with low ventilation rates (Kovler 2009). In most cases, radon comes from the ground in granite areas, but the source can be from granite floor materials thus polluting indoor air. Chen et al. (2010) analysed 33 different types of granites and mentioned that only two of them had exhalation rates above $200 \mathrm{~Bq} / \mathrm{m}^{2} \mathrm{~d}$. These authors studied the joint influence of the indoor air ventilation rate and the granites exhalation rates serving as floor materials, concluding that the highest exhalation rate of granite serving as floor material in a place with a low ventilation rate (air changes per hour, $\mathrm{ACH}=0.3$ ) contributed only to $18 \mathrm{~Bq} / \mathrm{m}^{3}$ of the total concentration (Table 4). To ACH levels near zero of high exhalation rate, granite can effectively be responsible for toxic radioactive concentrations. Other cases of radioactive building materials can be found in the literature, in Sweden 300,000 residential buildings were made with concrete based on aggregates from a uranium mine (alum shale). Recent studies revealed that infants and children were more prone to develop leukaemia-related diseases (Axelson et al. 2002).

\section{Lead plumbing}

Due to its low corrosion characteristics, lead has been used as water pipe material since the Roman Empire (Hodge 1981, Dutrizac et al. 1982, Nriagu 1983). Several authors mentioned that lead plumbing is responsible for health problems, because a film of corrosion products is formed on the pipe's surface that eventually will be leached away, thus contaminating water (Zietz et al. 2009). This contamination is particularly toxic to infants and children, causing behavioural problems and intellectual impairment (Pocock et al. 1994, Canfield et al. 2003, Wilhelm and Dieter 2003). Troesken (2006) refers to several cases of lead poisoning due to lead plumbing during the last two centuries, a problem as big as the Chernobyl or Bhopal disasters. This author states that not only in the USA thousands of children have died due to lead poisoning but also many suffered from intellectual impairment. A blood lead content higher than $10 \mu \mathrm{g} / \mathrm{dl}$ is considered to be the threshold for lead poisoning

Table 3. Typical and maximum activity concentrations in common building materials and industrial by-products used for building materials in Europe (Kovler et al. 2002, Kovler 2009).

\begin{tabular}{|c|c|c|c|c|c|c|}
\hline \multirow[b]{2}{*}{ Material } & \multicolumn{3}{|c|}{ Typical activity concentration $(\mathrm{Bq} / \mathrm{kg})$} & \multicolumn{3}{|c|}{ Maximum activity concentration $(\mathrm{Bq} / \mathrm{kg})$} \\
\hline & ${ }^{226} \mathrm{Ra}$ & ${ }^{232} \mathrm{Th}$ & ${ }^{40} \mathrm{~K}$ & ${ }^{226} \mathrm{Ra}$ & ${ }^{232} \mathrm{Th}$ & ${ }^{40} \mathrm{~K}$ \\
\hline \multicolumn{7}{|l|}{ Construction materials } \\
\hline Concrete & 40 & 30 & 400 & 240 & 190 & 1600 \\
\hline Light-weight concrete & 60 & 40 & 430 & 2600 & 190 & 1600 \\
\hline Ceramic bricks & 50 & 50 & 670 & 200 & 200 & 2000 \\
\hline Concrete blocks & 10 & 10 & 330 & 25 & 30 & 700 \\
\hline Natural stone & 60 & 60 & 640 & 500 & 310 & 4000 \\
\hline Natural gypsum & 10 & 10 & 80 & 70 & 100 & 200 \\
\hline \multicolumn{7}{|l|}{ Industrial by-products } \\
\hline Phosphogypsum & 390 & 20 & 60 & 1100 & 160 & 300 \\
\hline Blast furnace slag & 270 & 70 & 240 & 2100 & 340 & 1000 \\
\hline Coal fly ash & 180 & 100 & 650 & 1100 & 300 & 1500 \\
\hline
\end{tabular}


Table 4. Radon concentration $\left(\mathrm{Bq} / \mathrm{m}^{3}\right)$ due to radon exhalation from floor material according to the ventilation rate (Chen et al. 2010).

\begin{tabular}{lccccr}
\hline & \multicolumn{5}{c}{$\mathrm{ACH}$} \\
\cline { 2 - 6 } $\begin{array}{l}\text { Radon exhalation rate } \\
\left(\mathrm{Bq} / \mathrm{m}^{2} \mathrm{~d}\right)\end{array}$ & 3 & 1 & 0.3 & 0.15 & 0 \\
\hline 5 & 0.03 & 0.09 & 0.3 & 0.6 & 5 \\
10 & 0.06 & 0.2 & 0.6 & 1.2 & 25 \\
50 & 0.3 & 0.9 & 3.0 & 5.9 & 123 \\
100 & 0.6 & 1.8 & 6.0 & 12 & 246 \\
300 & 1.8 & 5.5 & 18 & 35 & 737 \\
\hline
\end{tabular}

(Labat et al. 2006, Tararbit et al. 2009), being associated with cardiovascular death and cancer development. Khalil et al. (2009) mentioned that a blood lead level higher than $8 \mu \mathrm{g} / \mathrm{dl}$ is responsible for increased mortality of coronary heart disease. Others (Menke et al. 2006) found out that a blood lead level higher than $2 \mu \mathrm{g} / \mathrm{dl}$ was associated with myocardial infarction and stroke mortality. Eventhough health-related risks due to lead pipe poisoning were known from quite sometime, in fact many cities in the USA tried to prohibit lead-based plumbing in the 1920s which was not enough to stop the counter actions of the lead pipe industry (Rabin 2008). In the 1970s, the World Health Organization (WHO) still admitted $300 \mu \mathrm{g} / \mathrm{l}$ as the threshold for lead in drinking water. Since then, this value has fallen significantly (Table 5) as suddenly the toxic risks of lead plumbing were made clear. Some how this threshold evolution is quite similar to the asbestos problem, in which increased patterns of restrictions were adopted until finally the final prohibition came. It is then no surprise to see that the related Directive (98/83/CE) established a 15 -year delay period before the $10 \mu \mathrm{g} / \mathrm{l}$ lead content threshold is enforced. This delay period is related to the cost of pipe substitution if the $10 \mu \mathrm{g} / \mathrm{l}$ lead content threshold was to be enforced immediately. For Portugal, the survey carried out in 1995 under the Directive (98/83/CE) revealed $1,177,300 \mathrm{~m}$ of lead pipes, as for Europe this amount reached almost 50 million metres. The replacement costs applied back then were almost

Table 5. Threshold evolution for lead in drinking water in the last decades.

\begin{tabular}{llc}
\hline Legal regulation & Year & $\begin{array}{c}\text { Threshold for } \\
\text { lead in drinking } \\
\text { water }(\mu \mathrm{g} / \mathrm{l})\end{array}$ \\
\hline $\begin{array}{l}\text { WHO } \\
\text { Directive } \\
(80 / 778 / \mathrm{CEE})\end{array}$ & 1970 & 300 \\
$\begin{array}{l}\text { Directive } \\
(98 / 83 / \mathrm{CE})\end{array}$ & $\begin{array}{l}\text { From 25 December 2003 } \\
\text { to 25 December 2013 }\end{array}$ & 50 \\
& After 25 December 2013 & 25 \\
\hline
\end{tabular}

34,000 million euros (Papadopoulos 1999). Estimates that are more recent refer to 200,000 million euros (Hayes 2009).

\section{Conclusions}

This present review confirms that a large amount of building materials present some form of toxicity. They may be toxic to the environment during the production stage or by polluting indoor air, by releasing toxic fumes during fires or simply by poisoning drinkable water also increases toxicity in building materials in the last decades, due to the reuse of industrial by-products and even some industrial wastes. Part of the problem is because architects and civil engineers have no form of knowing the toxicity of building materials meaning that something must be done at that level to address this problem. Unfortunately, one cannot count only on legal regulations because several building materials that comply with legal regulations thresholds remain toxic to human health. The toxicity of building materials relates to the existence of health-related investigations confirming this toxicity. Nevertheless, one must not forget that the past has showed us that some building materials that were considered safe or just inert have revealed to be very toxic afterwards. Furthermore, in some cases, legal regulations are influenced by economic reasons in the first place and only afterwards with the consequences for the human health. All this suggests that the choice of sustainable materials should see building materials as a key issue.

\section{Note}

1. Email: said@civil.uminho.pt

\section{References}

Akira, M., 2010. Asbestosis: IPF or NSIP-like lesions in asbestos-exposed persons, and such independency. Japanese Journal of Chest Diseases, 69, 38-44.

Antonescu-Turcu, A., and Schapira, R., 2010. Parenchymal and airway diseases caused by asbestos. Current Opinion in Pulmonary Medicine, 16, 155-161.

ASTDR, 2002. Toxicological profile for creosote. Agency for toxic substances and disease registry. Atlanta, GA: US Department of Health and Human Services, Public Health Sector, $11 \mathrm{p}$.

Axelson, O., et al., 2002. Leukemia in childhood and adolescence and exposure to ionizing radiation in homes built from uranium-containing alum shale concrete. Epidemiology, 13, $146-150$.

Azuma, K., et al., 2009. Mesothelioma risk and environmental exposure to asbestos: past and future trends in Japan. International Journal of Occupational and Environmental Health, 15, 166-172.

Bianchi, C., et al., 1997. Latency periods in asbestos-related mesothelioma of the pleura. European Journal of Cancer Prevention, 6, 162-166. 
Bruntland, 1987. Our common future: Report of the World Comission on Environment and Development. UN General Assembly document A/42/427, Oxford University Press.

Canfield, R., et al., 2003. Intellectual impairment in children with blood lead concentrations below $10 \mu \mathrm{g}$ per deciliter. New England Journal of Medicine, 348, 1517-1526.

Canut, M., 2006. Using phosphogypsum as building materials. Master thesis. University of Minas Gerais, Brasil.

Chen, J., Rahman, N., and Atiya, I., 2010. Radon exhalation from building materials for decorative use. Journal of Environmental Radioactivity, 101, 317-322.

Doroudiani, S., and Omidian, H., 2010. Environmental, health and safety concerns of decorative mouldings made of expanded polystyrene in buildings. Building and Environment, 45, 647-654.

Dutrizac, J., O'Reilly, J. and Macdonald, R., 1982. Roman lead plumbing: did it really contribute to the decline and fall of the empire. CIM Bulletin, 75, 111-115.

Edlich, R., Winters, K. and Long, W., 2005. Treated wood preservatives linked to aquatic damage, human illness, and death - a societal problem. Journal of Long-Term Effects of Medical Implants, 15, 209-223.

EPA, 1992. Potential uses of phosphogypsum and associated risks. Office of Radiation Programs 520/1-91-029, Washington.

Euratom, 1996. Council directive 96/29 EC, European Atomic Comission.

Flores, A., et al., 2004. Organochloride: a public health problem. Revista Ambiente \& Sociedade, 7, 111-124. (only in Portuguese)

Gann, R., et al., 1994. Fire conditions for smoke toxicity measurements. Fire Materials, 18, 193-199.

Hall, J., and Harwood, B., 1995. Smoke or burns - which is deadlier? National Fire Protection Association Journal, 38, $38-43$.

Hansen, S., and Burroughs, H., 1999. Classifying indoor air problems. Managing indoor air quality. USA: Fairmont Press, 62-63.

Hauser, R., and Calafat, A., 2005. Phthalates and human health. Occupational and Environmental Medicine, 62, 806-818.

Hayes, C., 2009. Plumbosolvency control. Best practice guide. IWA Specialista Group on Metals and Related Substances in Drinking Water, Cost 637.

Heudorf, U., Mersch-Sundermann, V. and Angerer, J., 2007. Phthalates: toxicolgy and exposure. International Journal of Hygiene and Environmental Health, 210, 623-634.

Hodge, A., 1981. Vitrivius, lead pipes and lead poisoning. American Journal of Archaeology, 85, 486-491.

IARC, 1997. Polychlorinated dibenzo-para-dioxins and polychlorinated dibenzofurans. IARC monographs on the evaluation of carcinogenic risks to humans, Vol. 69. Lyon: WHO.

ICRP, 1990. Recommendations of the international commission on radiological protection. ICRP Publication 60. Oxford: Pergamon Press.

IPCC, 2007. Intergovernmental Panel on Climate Change. Climate Change 2007 4th Assesment report (www.ipcc.ch).

Jarvholm, B., Englund, A. and Albin, M., 1999. Pleural mesothelioma in Sweden: an analysis of the incidence according to the use of asbestos. Occupational and Environmental Medicine, 56, 110-113.

Khalil, N., et al., 2009. Association of blood lead concentrations with mortality in older women: a prospective cohort study. Environmental Health: A Global Access Science Source, 8, $15-27$.
Kostianien, R., 1995. Volatile organic compounds in the indoor air of normal and sick houses. Atmosferic Environment, 29, $693-702$.

Kovler, K., 2009. Radiological constraints of using building materials and industrial by-products in construction. Construction and Building Materials, 23, 253-264.

Kovler, K., et al., 2002. Natural radionuclides in building materials available in Israel. Building and Environment, 37, $531-537$.

Kwok, N., et al., 2003. Substrate effects on VOC emissions from an interior finishing varnish. Building and Environment, 38, 1019-1026.

Labat, L., et al., 2006. Variabilité de la mesure de la plombémie pour de faibles concentrations proches du seuil de $100 \mu \mathrm{g} / \mathrm{l}$ : étude multicentrique [Variation of measurements in lead pipes for low concentrations near $100 \mathrm{Mg} / \mathrm{l}$ : multicenter study]. Annals of Toxicology, 18, 297-304.

Ladou, J., 2004. The asbestos cancer epidemic. Environmental Health Perspectives, 112, 285-290.

Lanting, C., et al., 1998. Neurologic condition in 42-month-old children in relation to pre- and post-natal exposure to polychlorinated biphenyls and dioxins. Early Human Development, 50, 700-706.

Levin, B., and Kuligowski, E., 2005. Toxicology of fire and smoke. In: H. Salem and S. Katz, eds. Inhalation toxicology. Boca Raton, FL: CRC Press, 205-228.

Liang, H., and Ho, M., 2007. Toxicity characteristics of commercially manufactured insulation materials for building applications in Taiwan. Construction and Building Materials, 21, 1254-1261.

Lovekamp-Swan, T., and Davis, B., 2003. Mechanisms of phthalate ester toxicity in the female reproductive system. Environmental Health Perspectives, 111, 139-145.

Meadows, D.L., Meadows, D.L. and Behrene, J.R.W., 1972. The limit to growth. MIT Press.

Meeker, J., et al., 2009. Urinary phthalate metabolites in relation to preterm birth in Mexico city. Environmental Health Perspectives, 117, 1587-1592.

Menke, A., et al., 2006. Blood lead below $0.48 \mu \mathrm{mol} / \mathrm{l}(10 \mu \mathrm{g} / \mathrm{dl})$ and mortality among us adults. Circulation, 114, 1388-1394.

Morrell, J., 2002. Wood-based building components: what have we learned. International Biodeterioration, 49, 253-258.

Nriagu, J., 1983. Saturnine gout among roman aristocrats. Did lead poisoning contribute to the fall of the empire? New England Journal of Medicine, 308, 660-663.

Oppenhuizen, A., and Sijm, D., 1990. Bioaccumulation and biotransformation of poluchlorinated dibenzo-p-dioxins and dibenzofurans in fish. Environmental Toxicology and Chemistry, 9, 175-186.

Papadopoulos, I., 1999. Revision of the council directive on the quality of water intended for human consumption. The Environmentalist, 19, 23-26.

Papaefthmiou, H. and Gouseti, O., 2008. Natural radioactivity and associated radiation hazards in building materials used in Peloponnese, Greece. Radiation Measurements, 43, 1453-1457.

Pocock, S., Smith, M. and Baghurst, P., 1994. Environmental lead and children's intelligence: a systematic review of the epidemiological evidence. British Medical Journal, 309, 1189-1197.

Pruszinski, A., 1999. Review of the landfill disposal risks and the potential for recovery and recycling of preservative treated timber. Environmental Protection Agency Report. 
Rabin, R., 2008. The lead industry and lead water pipes 'a modest campaign'. American Journal of Public Health, 98, 1584-1592.

Rihanek, S., 1971. Radioactivity of phosphate plaster and phosphate gypsum. Tonind-Ztg, 95, 264-270.

Salasar, C., 2007. Study about VOC's emission from solvent and water based paints. Master thesis. University of Londrina, Brazil. (only in Portuguese)

Samfield, M., 1992. Indoor air quality data base for organic compounds. EPA-600/13.

Satyanand, T., 2008. Aftermath of the Bhopal accident. The Lancet, 371, 1900. DOI: 10.1016/30140-6736(08)60814-4.

Stern, N., 2006. Stern review on economics of climate change. Cambridge University Press.

Silverstein, M., Welch, L. and Lemen, R., 2009. Developments in asbestos cancer risk assessment. American Journal of Industrial Medicine, 52, 850-858.

Smith, P., 2008. Risks to human health and estuarine ecology posed by pulling out creosote-treated timber on oyster farms. Aquatic Toxicology, 86, 287-298.

Sterling, D., 1985. Volatile organic compounds in indoor air. An overview of sources, concentrations, and health effects. In: R. Gammage and V. Jacobs, eds. Indoor air and human healths, Chelsea, MI: Lewis Publisher, Inc., 387.

Swan, S., 2008. Environmental phthalate exposure in relation to reproductive outcomes and other health endpoints in humans. Environmental Research, 108, 177-184.

Tararbit, K., Carré, N. and Garnier, R., 2009. Occurrence of lead poisoning during follow-up of children at risk wih initial screening lead blood levels below $100 \mu \mathrm{g} / \mathrm{l}$. Revue D'Epidemiologie et de Sante Publique, 57, 249-255.

Thierfelder, T. and Sandstrom, E., 2008. The creosote content of used railway crossties as compared with european stipulations for hazardous waste. Science of the Total Environment, 24, 106-112.

Thornton, J., 2000. Pandora's poison: chlorine, health, and a new environmental strategy. Cambridge, MA: MIT Press. ISBN 0-262-20124-0.

Tillitt, D., et al., 1993. Dioxin-like toxic potency in Forster's tern eggs form Green Bay, Lake Michigan, North America. Chemosphere, 26, 2079-2084.

Troesken, W., 2006. The great lead water pipe disaster. Cambridge: MIT Press.

Varma, R. and Mulay, S., 2006. The Bhopal accident and methyl isocyanate toxicity. Toxicology of Organophosphate \& Carbonate Compounds, 7, 79-88.

Wilhelm, M. and Dieter, H., 2003. Lead exposure via drinking water-unnecessary and avoidable. Umweltmedizin in Forschung nd Praxis, 8, 239-241.

Wolff, M., et al., 2008. Prenatal phenol and phthalate exposures and birth outcomes. Environmental Health Perspectives, 116, 1092-1097.

Wu, C., 2001. Discussion on fire safety factors from case studies of building fires. Master thesis. University of Tainan, Taiwan.

WWI - World Watch Institute, 2009. State of the World 2009 Into a warming world.

Zietz, B., et al., 2009. Lead pollution of drinking water in lower Saxony from corrosion of pipe materials. Gesundheitswesen, $71,265-274$. 